\title{
Analysis of Combustion Characteristics of Waste Plastic Disposal Fuel (WPDF) and Tire Derived Fuel (TDF)
}

\author{
Mohd. Herzwan Hamzah ${ }^{1, a}$, Abdul Adam Abdullah ${ }^{1, b}$ Agung Sudrajad ${ }^{2, c}$, \\ Nur Atiqah Ramlan ${ }^{1, \mathrm{~d}}$, Nur Fauziah Jaharudin ${ }^{1, \mathrm{e}}$ \\ ${ }^{1}$ Faculty of Mechanical Engineering, Universiti Malaysia Pahang, 26600, Pekan, Pahang, Malaysia \\ ${ }^{2}$ Department of Mechanical Engineering, University of Sultan Ageng Tirtayasa, Jalan Jakarta \\ Merak KM 4, Serang, Banten, Indonesia \\ a herzwan@gmail.com, ${ }^{\mathrm{b}}$ adam@ump.edu.my, ${ }^{\mathrm{c}}$ goenkobe@yahoo.com, \\ datiqahramlan3@gmail.com, ${ }^{\mathrm{e}}$ fauziahjs@gmail.com
}

Keywords: waste plastic disposal fuel, tire derived fuel, diesel engine, alternative fuel

\begin{abstract}
The increase of industrial activities and motor vehicles globally causes rise demands in fossil fuel as energy sources. Since fossil fuel is non-renewable energy, many researches have been conducted to reduce the reliance to this fossil fuel. In conjunction, the number of waste plastic and tires around the world is increasing as a result of modern application and increasing number of motor vehicle. This type of waste is hard to decays and commonly dumped onto open landfills. Utilization of waste tires and plastics can produce alternative fuel that potentially can be used in diesel engine. In this paper, the combustion characteristics of two waste source fuels known as waste plastic disposal fuel (WPDF) and tire disposal fuel (TDF) are discussed. The combustion characteristics of both fuels are compared to diesel fuel. WPDF and TDF used in this experiment are pure concentrated and not blended with diesel fuel. The experiment is conducted using single cylinder YANMAR TF120M diesel engine. The engine is operated at constant load at $20 \mathrm{Nm}$ and variable speed ranged from $1200 \mathrm{rpm}$ to $2400 \mathrm{rpm}$. The combustion characteristics that discussed in this paper are ignition delay and peak pressure. Both characteristic are measured at two engine speed region which is low speed $(1200 \mathrm{rpm})$ and high speed $(2100 \mathrm{rpm})$. From the results obtained, it can be observed that WPDF has comparable ignition delay compared to diesel fuel while TDF has longest ignition delay compared to WPDF and diesel fuel. TDF also produce highest peak pressure compared to other tested fuels. Moreover, TDF is not suitable for high speed application since it cause backfire when engine speed reach $2200 \mathrm{rpm}$.
\end{abstract}

\section{Introduction}

Diesel engine is preferred power source in many applications such as agriculture, automobile and marine due to its high efficiency, high driveability and robustness. However, due to increasing number of diesel engine around the globe, the demand for diesel fuel is increasing. Since diesel fuel is non-renewable energy source, many researches have been conducted to produce alternative fuel for diesel engine. One common example of alternative fuel that used for diesel engine is biodiesel. Biodiesel is favoured as alternative fuel for diesel engine since it can be used directly in diesel engine without modification.

Due to wide application of plastics and increasing number of vehicles, the production of waste plastics and waste tires are increasing. In Malaysia, most of the solid waste including tires and plastics are disposed through landfills. According to Budhiarta [1], plastics are the second highest in percentage in municipal solid waste after food waste in Kuala Lumpur. Furthermore, Kementerian Kesejahteraan Bandar, Perumahan dan Kerajaan Tempatan [2] stated that Malaysia generate 774 tonnes of waste tires per day in 2013. Since the number of vehicles in Malaysia is increasing as reviewed by Ahmad [3], the number of scrap tires will increase significantly.

Utilization of waste plastics and tires will produce a fuel that potentially can be used as alternative fuel for diesel engine. Both fuel is produced through thermal degradation process with absence of oxygen which known as pyrolysis process. Experiment that conducted by Panda [4] 
concluded that pyrolysis can be performed with or without catalyst where the catalyst affect the yield rate of the liquid fuel. The temperature used in the process is between $350-500^{\circ} \mathrm{C}$.

Engine performance of diesel engine operating with TDF has been investigated by Murugan [5]. In the experiment, the TDF is blended with diesel fuel at several blend ratios. It is concluded that brake thermal efficiency (BTE) is increase with increment of TDF blend ratio in diesel fuel and all of the blend yields higher BTE compared to diesel fuel. The ignition delay, peak pressure and rate of pressure rise of blended TDF are longer compared to diesel fuel.

Mani [6] studied WPDF performance output when used in diesel engine. It is stated that the diesel engine can operate with 100\% WPDF. The result also shows that WPDF produce stable performance output with similar BTE compared to diesel fuel. The ignition delay, $\mathrm{NO}_{\mathrm{x}}, \mathrm{CO}$ and unburned hydrocarbon is higher compared to diesel fuel. The peak pressure of WPDF is also higher compared to diesel fuel. However, smoke is reduced by $40 \%$ to $50 \%$ when waste plastic fuel is used compared to diesel fuel.

\title{
Experimental Setup and Details
}

The schematic diagram for experimental setup is shown in Figure 1. A direct-injection, single cylinder water cooled diesel engine (YANMAR TF 120M) is used in this research. The engine specifications are shown in Table 1. During experiment, the engine was tested without any modifications throughout the experiment.

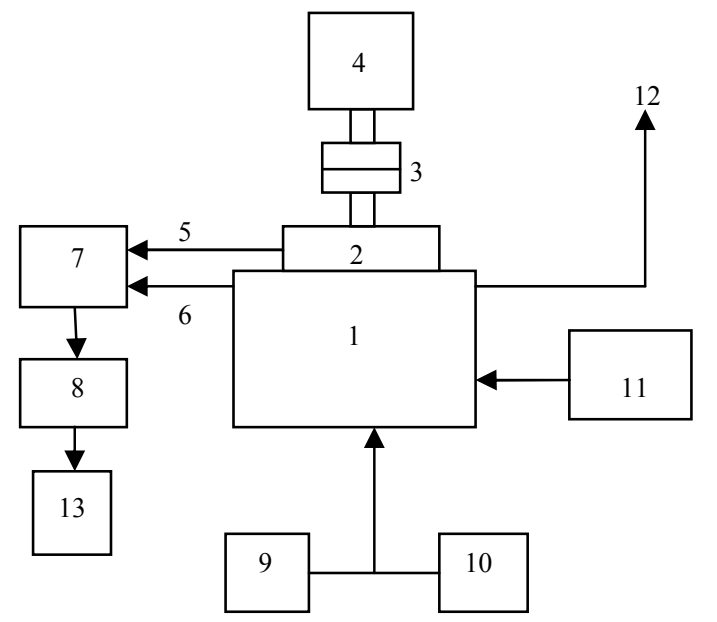

\author{
Diesel engine YANMAR TF120M \\ Engine flywheel \\ NBK Flexible coupling \\ Hydraulic gear pump (dynamometer) \\ Crank angle sensor \\ Pressure sensor \\ Sensor interface \\ LCS Data logger \\ Diesel fuel tank \\ Alternative fuel tank \\ Airbox \\ Exhaust manifold \\ Computer
}

Figure 1: Experimental Setup

The engine is coupled using NBK coupling to a positive displacement Hydrome HGP-3F-23 gear pump which functions as hydraulic dynamometer. An airbox is fitted to the engine intake manifold for airflow measurement. The data are taken using TFX Engineering DAQ system which consists of in-cylinder pressure sensor and crank angle sensor. The exhaust temperature, ambient temperature and intake temperature are measured using K-type thermocouples. The thermocouples are placed at exhaust manifold, intake manifold and air measurement unit.

The engine speed parameter is set at five different speeds which are $1200 \mathrm{rpm}, 1500 \mathrm{rpm}$, $1800 \mathrm{rpm}, 2100 \mathrm{rpm}$ and $2400 \mathrm{rpm}$ and constant load at $20 \mathrm{Nm}$ is exerted to the engine. The engine is run at desired engine speed at the beginning of each setup. Then, the load is exerted to the engine after stable operating condition is achieved. The data is taken after the load exerted where the speed measurement remain stable for at least one minute. The engine is run using conventional diesel fuel at the beginning to obtain base data for comparison.

For test fuel data measurement, the engine is run with diesel fuel for beginning. After five minutes running on diesel fuel, the valve supplying the diesel fuel to the engine is closed and after a while, the valve for supplying test fuel into the engine is opened. The engine is let running for at 
least five minute before the data is taken to ensure only the test fuel is injected into the combustion chamber. The combustion characteristic curve is measured using in-cylinder pressure sensor and crank angle sensor. All the testing procedures are repeated as WPDF is used as fuel in diesel engine. The chemical properties for diesel, TDF and WPDF used in the experiment are shown in Table 2.

Table 1: Engine specification

Table 2: Chemical properties of test fuels

\begin{tabular}{|c|c|c|c|c|c|c|}
\hline \multirow{6}{*}{$\begin{array}{l}\text { Engine type } \\
\text { Bore x stroke } \\
\text { Displacement } \\
\text { Compression } \\
\text { ratio }\end{array}$} & \multirow{3}{*}{$\begin{array}{l}\text { Specification } \\
\text { YANMAR TF120M } \\
92 \times 96 \mathrm{~mm} \\
0.638 \mathrm{~L}\end{array}$} & \multicolumn{2}{|l|}{ Properties } & \multirow{2}{*}{$\begin{array}{c}\text { Diesel } \\
0.841 \\
55\end{array}$} & \multirow{2}{*}{$\begin{array}{c}\text { WPDF } \\
0.771 \\
51^{[6]}\end{array}$} & \multirow{2}{*}{$\begin{array}{c}\text { TDF } \\
0.923 \\
42^{[8]}\end{array}$} \\
\hline & & $\begin{array}{l}\text { Density } \\
\text { Cetane Number }\end{array}$ & {$\left[\mathrm{g} / \mathrm{cm}^{3}\right]$} & & & \\
\hline & & $\begin{array}{l}\text { Kinematic Viscosity } \\
\text { (a) } 40^{\circ} \mathrm{C}\end{array}$ & [cst] & 3.05 & 2.149 & 5.1 \\
\hline & 177 & Flash Point & {$\left[{ }^{\circ} \mathrm{C}\right]$} & 84 & 72 & 44 \\
\hline & 17.1 & Gross cal. Value & {$[\mathrm{MJ} / \mathrm{kg}]$} & 42.49 & 34.72 & 38 \\
\hline & $17^{\circ} \mathrm{BTDC}$ & $\begin{array}{l}\text { Boiling Point } \\
\text { (ASTM D4249) }\end{array}$ & {$\left[{ }^{0} \mathrm{C}\right]$} & 193 & 186 & 127 \\
\hline Rated output & $12 \mathrm{HP}$ at $2400 \mathrm{rpm}$ & $\begin{array}{l}\text { Sulphur content } \\
\text { (ASTM D 86) }\end{array}$ & [\%] & 0.042 & 0.019 & 0.811 \\
\hline
\end{tabular}

\section{Result and Discussions}

Figure 2 shows the combustion characteristics at low speed which is $1200 \mathrm{rpm}$. The performance characteristics of diesel fuel, TDF and WPDF are measured. From the figure, two regions are focused which is ignition delay in region 'A' and peak pressure in region 'B'. From the curve, it can be seen that WPDF has nearly same ignition delay compared to diesel fuel which about $1^{\circ}$ bTDC. However, TDF has longer ignition delay compared to WPDF and diesel fuel where ignition starts at $1^{\circ}$ aTDC.

The difference of ignition delay for the tested fuels can be related to the cetane number of the fuels. TDF has longest ignition delay compared to WPDF and diesel fuel because of TDF has the lowest cetane number compared to the other tested fuels. Moreover, TDF has higher kinematic viscosity thus producing bigger fuel droplets when the fuel is injected into the combustion chamber. Bigger fuel droplet will have smaller surface area thus causing poor mixing rate between fuel and air. This condition will cause late formation of combustible air-fuel mixture thus prolong the ignition delay.

Referring to the Table 2, WPDF has lower cetane number compared to diesel fuel. This supposedly cause will cause WPDF has longer ignition delay compared to diesel fuel. However, since WPDF has lower kinematic viscosity compared to diesel fuel, it will form finer fuel droplets hence the ignitable air-fuel mixture will form at faster rate. This factor make WPDF has comparable ignition delay compared to diesel fuel even though it has lower cetane number compared to diesel fuel.

From region B in Figure 2, it can be seen that the peak pressure of TDF is the highest which is 80.2 bar at $5^{\circ}$ aTDC. Diesel fuel produce second highest peak pressure which is 76.6 bar aTDC and WPDF produce lowest peak pressure which is 73.1 bar at $6^{\circ}$ aTDC. TDF produce highest peak pressure compared to other tested fuel because of its longest ignition delay. Longer ignition delay cause more fuel entering the combustion chamber during the delay period, hence cause rapid and higher pressure rise when the combustion occur. WPDF produce lowest peak pressure because of its lower gross calorific value compared to TDF and diesel fuel. This factor cause lower peak pressure when WPDF is combusted.

Figure 3 shows the combustion characteristics at high speed which is $2100 \mathrm{rpm}$. From the figure, it can be seen that the ignition delay for WPDF and diesel fuel is almost the same which is $1^{\circ}$ aTDC. This condition may relate to the higher cetane number of diesel fuel and lower kinematic viscosity for WPDF. Lower kinematic viscosity cause finer fuel droplets as the fuel is injected into the combustion chamber thus shorter amount of time needed for combustible air-fuel mixture to be formed [7]. This cause WPDF and diesel fuel have comparable ignition delay each other. TDF has 
longest ignition delay compared to other tested fuels which is $8^{\circ}$ aTDC. Compared to the Figure 2, the ignition delay of TDF is about $1^{\circ}$ aTDC when the engine speed is in low speed region which is $1200 \mathrm{rpm}$. This trend shows that TDF will have longer ignition delay in terms of crank angle as the engine speed increase. This is because TDF has lowest cetane number compared to diesel fuel and WPDF.
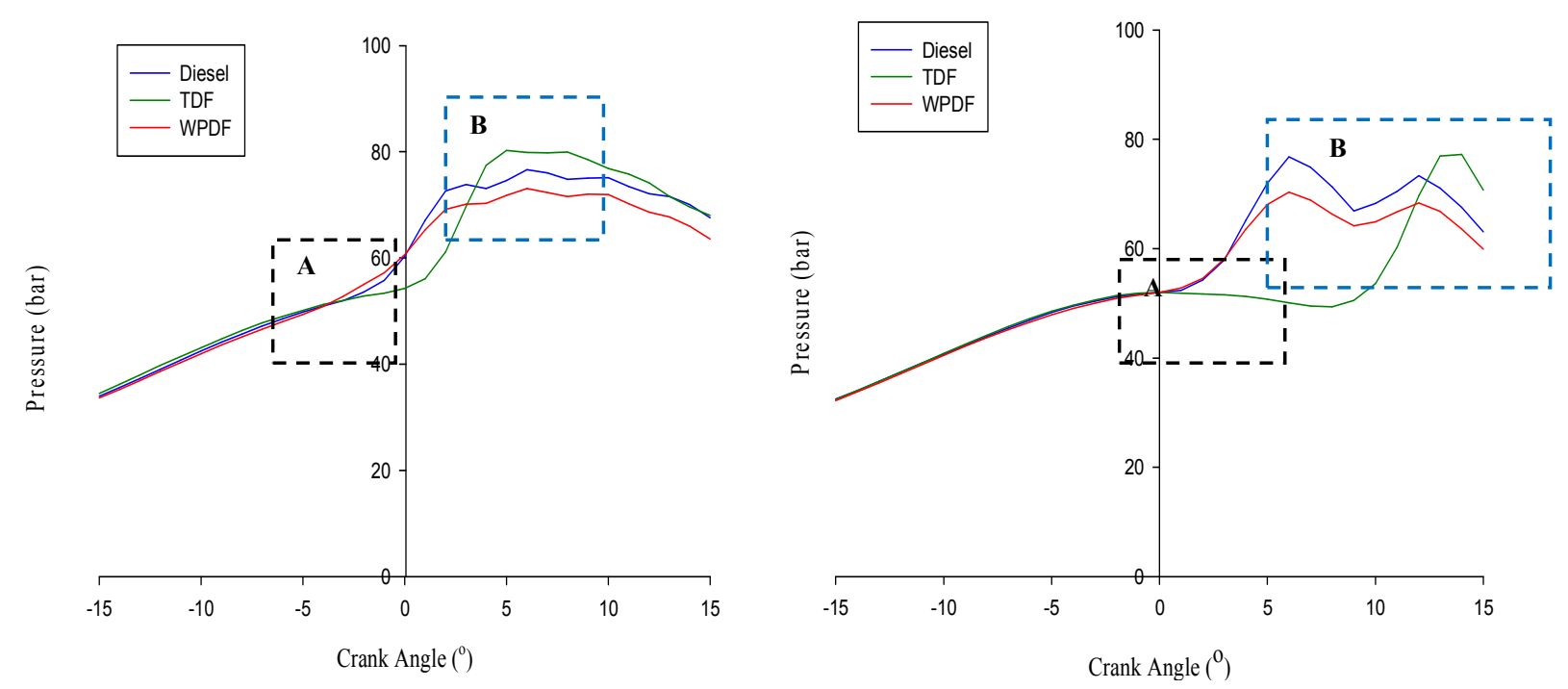

Figure 2: Combustion characteristics at 1200 rpmFigure 3: Combustion characteristics at $2100 \mathrm{rpm}$

Region B in Figure 3 shows the peak pressure of all tested fuels at $2100 \mathrm{rpm}$. From the figure, it can be seen that TDF produce highest peak pressure which is 77.2 bar. Diesel fuel produces second highest pressure which is 76.7 bar and WPDF produce lowest peak pressure which is 70.3 bar. TDF produce highest peak pressure because it has the longest ignition delay compared to diesel fuel and WPDF. Longer ignition delay cause more fuel entering combustion chamber during delay period and cause more rapid and higher pressure rise compared to other fuel. WPDF has lowest peak pressure compared to diesel fuel and TDF because of its lower gross calorific value. Lower gross calorific value cause less energy released as the fuel

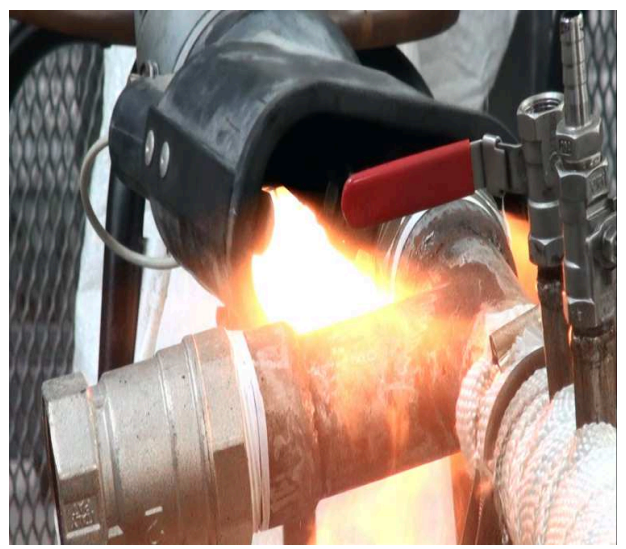

Figure 4: Backfire Phenomenon combusted thus cause lower peak pressure.

Figure 4 shows the backfire phenomenon. This phenomenon occurs when TDF is used in diesel engine and the engine speed reach high speed region which is exceeds $2200 \mathrm{rpm}$. When the engine speed exceeds $2200 \mathrm{rpm}$, the engine starts to have unstable engine operation. Next, explosion sound occurs at exhaust manifold followed by backfire as shown in Figure 4.

This phenomenon is related to longer ignition delay of TDF as the engine speed increase. When engine speed exceeds $2200 \mathrm{rpm}$, longer ignition delay of TDF will cause some of the unburned fuel enters the exhaust manifold. Heat from the exhaust manifold will cause the unburned fuel combust in the exhaust manifold. This phenomenon will cause poor engine performance and worse emission level. This phenomenon shows that TDF is not suitable for high speed application. 


\section{Conclusion}

In this study, the combustion characteristics of TDF and WPDF have been investigated and compared to diesel fuel. The results obtained shows that diesel engine can operate with $100 \%$ WPDF and TDF. TDF produce highest peak pressure and longest ignition delay compared to other fuel at both engine speed region. However, overall results show that WPDF has more comparable combustion characteristics to diesel fuel than TDF.

\section{References}

[1] Budhiarta, I., Siwar, C. \& Basri, H. 2012. Current Status of Municipal Solid Waste Generation in Malaysia. International Journal on Advanced Science Engineering Information Technology, 2.

[2] Lab Pengurusan Sisa Pepejal. 2012. Slide. Malaysia. Kementerian Kesejahteraan Bandar, Perumahan dan Kerajaan Tempatan.

[3] Ahmad, A. 2012. Market review for 1st half 2012 compared to 1st half 2011. Malaysian Automotive Association.

[4] Panda, A. K., Singh, R. K. \& Mishra, D. K. 2010. Thermolysis of waste plastics to liquid fuel; A suitable method for plastic waste management and manufacture of value added products-A world prospective. Renewable and Sustainable Energy Reviews, 14, 233-248.

[5] Murugan, S., Ramaswamy, M. C. \& Nagarajan, G. 2008. The use of tyre pyrolysis oil in diesel engines. Waste Management, 28, 2743-2749.

[6] Mani, M., Subash, C. \& Nagarajan, G. 2009. Performance, emission and combustion characteristics of a DI diesel engine using waste plastic oil. Applied Thermal Engineering, 29, 2738-2744.

[7] Adam, A., Rizalman, M., Kidoguchi, Y. \& Yatsufusa, T. 2011. Analysis of Straight Vegetable Oil (SVO) Spray Characteristics and Droplets Distribution by Using Nano-Spark Shadowgraph Photography Technique. The Third International Renewable Energy Congress. Hammamet Tunisia.

[8] Bhatt, M. P. \& Patel, D. P. 2012. Suitability of Tyre Pyrolysis Oil (TPO) as an Alternative Fuel for Internal Combustion Engine. International Journal of Advanced Engineering Research and Studies, 1, 61-65. 